\title{
IMPLEMENTASI PADAT KARYA TUNAI DANA DESA UNTUK MASYARAKaT MISKIN DI KABUPATEN PASURUAN DAN Kabupaten Probolinggo
}

e-ISSN: 2549-5283

p-ISSN: 2549-5151

Matra Pembaruan 4 (1) (2020):

25-35

DOI:

10.21787/mp.4.1.2020.25-35

Keywords: Village Funds, Cash For Work, Workers' Day

Kata Kunci: Dana Desa, Padat Karya Tunai, Hari Orang Kerja

Korespondensi
Phone $\quad$ : +62 81906311297
Email $\quad$ : aslamshofi2@gmail.com

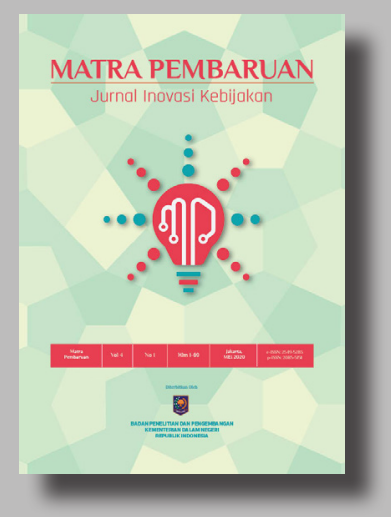

BADAN PENELITIAN DAN PENGEMBANGAN (BPP) KEMENTERIAN DALAM NEGERI

Jl. Kramat Raya No 132, Jakarta Pusat, 10450

(C)Irfan Sofi

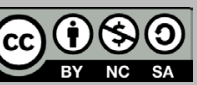

Karya ini dilisensikan di bawah Lisensi Internasional Creative Commons Atribusi Nonkomersial Sharealike 4.0.

\section{Irfan Sofi ${ }^{*}$}

Analis Keuangan Pusat dan Daerah, Direktorat Jenderal Perimbangan Keuangan, Kementerian Keuangan Jl. Dr. Wahidin No. 1 Jakarta Pusat

Dikirim: 05 Maret 2020; Direvisi: 20 April 2020; Disetujui: 20 April 2020

\begin{abstract}
The Village Fund began to be allocated in the 2015 APBN after the issuance of Law Number 6 of 2014 concerning Village. Inequality, poverty and unemployment in villages are still a problem today. 1In 2018 there is a new policy on the implementation of the Village Fund, which is Cash for Work in The Village (CfWV) to overcome this problem. The purpose of this article are 1) to find out the implementation of $C f W V$, and 2) obstacles to $C f W V$. This article uses qualitative research methods using triangulation of data validation techniques, namely observation, interview and literature study. The article found, CfWV is capable of a minimum of 55 workers for each activity and the average fulfillment of Workers' Day (HOK) still requires 30 percent. CfWV also reduces the spirit of mutual cooperation in the village. The conclusion of this article is that CfWV in 2018 has generally run well and is very useful in increasing the income of the people, especially the poor.
\end{abstract}

\section{Intisari}

Dana Desa mulai dialokasikan dalam APBN 2015 setelah keluarnya UU No 6 Tahun 2014 tentang Desa. Ketimpangan, kemiskinan dan pengangguran di desa masih menjadi permasalahan saat ini. Pada 2018 terdapat kebijakan baru pelaksanaan dana desa yaitu Padat Karya Tunai (PKT) untuk mengatasi persoalan tersebut. Tujuan dari artikel ini yaitu 1) Untuk mengetahui implementasi pelaksanaan Padat Karya Tunai Dana Desa, dan 2) Kendala pelaksanaan Padat Karya Tunai Dana Desa. Artikel ini menggunakan metode penelitian kualitatif dengan menggunakan teknik validasi data secara triangulasi yaitu observasi, wawancara dan studi pustaka. Artikel ini menemukan, PKT dana desa mampu menyerap minimal 55 tenaga kerja untuk setiap kegiatan dan rata-rata pemenuhan Hari Orang Kerja (HOK) masih di bawah 30 persen. PKT dana desa juga membuat berkurangnya semangat gotong royong di desa. Kesimpulan dalam artikel ini yaitu PKT Dana pada 2018 secara umum berjalan dengan baik dan sangat bermanfaat meningkatkan pendapatan masyarakat khususnya masyarakat miskin. 


\section{Pendahuluan}

Dana Desa adalah dana dari Anggaran Pendapatan dan Belanja Negara (APBN) yang diperuntukan bagi Desa, yang ditransfer melalui Anggaran Pendapatan dan Belanja Daerah (APBD) Kabupaten/Kota dan diprioritaskan untuk pembangunan dan pemberdayaan masyarakat, sebagaimana ketentuan UU No 6 Tahun 2014 tentang Desa (Ardiana dan Tjukup, 2018). Pemerintah mengalokasikan dana desa dengan tujuan untuk meningkatkan pelayanan publik di desa, mengentaskan kemiskinan, memajukan perekonomian desa dan mengatasi kesenjangan pembangunan antardesa. Dana Desa pertama kali disalurkan ke desa pada 2015. Tahun 2018 merupakan tahun keempat pelaksanaan dari dana desa di mana pemerintah mengalokasikan anggaran dalam APBN sejumlah Rp70 triliun untuk sekitar 74.953 desa.

Tabel 1

Perkembangan Dana Desa Tahun 2015 - 2019

\begin{tabular}{cccc} 
Tahun & Desa & $\begin{array}{c}\text { Alokasi } \\
\text { (Triliun) }\end{array}$ & $\begin{array}{c}\text { Rata-Rata } \\
\text { Perdesa (Juta) }\end{array}$ \\
\hline 2015 & 74.093 & 20,7 & 280,72 \\
\hline 2016 & 74.754 & 46,9 & 628,49 \\
\hline 2017 & 74.910 & 60,0 & 800,49 \\
\hline 2018 & 74.958 & 60,0 & 800,45 \\
\hline 2019 & 74.953 & 70,0 & 933,92 \\
\hline Jumlah & & 257,6 & \\
\hline
\end{tabular}

Sumber : Ditjen PMD, Kemendagri 2020

Besarnya dana yang digelontorkan dari APBN ke desa harus diikuti dengan perbaikan-perbaikan di desa baik pengelolaan keuangan (Nafidah dan Anisa, 2017), maupun fasilitas infrastruktur yang ada di desa untuk memaksimalkan pelayanan kepada masyarakat desa. Sebagian besar dana desa digunakan untuk pembangunan infrastruktur di desa (Anshari, 2017). Sudah banyak yang dihasilkan dari Dana Desa di bidang pembangunan antara lain jalan desa, drainase, talud, embung desa, PAUD, posyandu, dan lain-lain.

Penelitian Darmi dan Mujtahid (2019) menunjukkan bahwa dana desa belum berkontribusi nyata terhadap penurunan jumlah penduduk miskin dan belum menjadi akselerator dalam mengentaskan kemiskinan. Selanjutnya penelitian Wahyuddin, dkk (2019) menunjukkan bahwa variabel dana desa berpengaruh positif dan signifikan terhadap kemiskinan. Namun demikian, berdasarkan data dari Badan Pusat Statistik (BPS) menunjukkan bahwa persentase penduduk miskin perdesaan mengalami penurunan dari 13,96 persen $(9 / 2017)$ menjadi 13,20 persen $(3 / 2018)$.
Jika secara nasional persentase penduduk miskin sebesar 9,82 persen maka masih jauh jaraknya yaitu sekitar 3,38 persen.

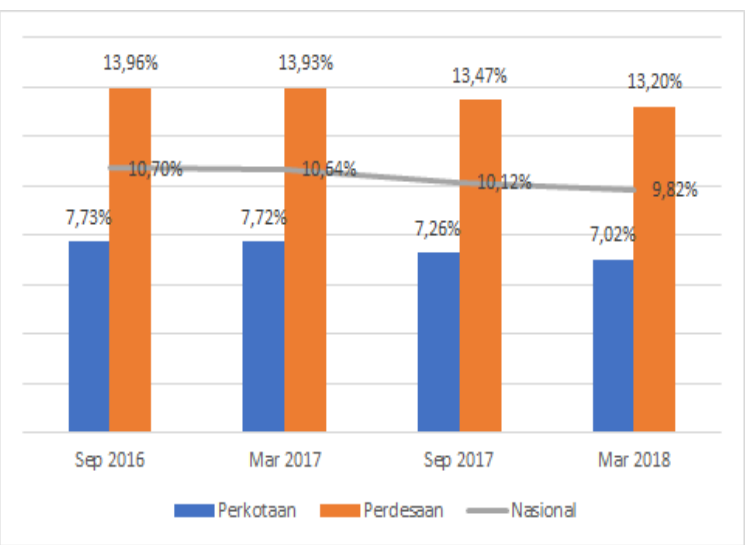

Gambar 1.

Persentase Penduduk Miskin Menurut Perkotaan dan Perdesaan Sumber : BPS 2019 (diolah)

Sebaliknya, data gini ratio perdesaan menunjukkan bergerak naik. Berdasarkan data BPS di bulan Maret 2018, angka gini ratio perdesaan sebesar 0,324 atau naik sebesar 0,004 dari tahun sebelumnya yaitu diangka 0,320 . Angka ini menunjukkan terjadi kesenjangan bertambah melebar di perdesaan. Perkembangan gini ratio dapat kita lihat dalam gambar 2.

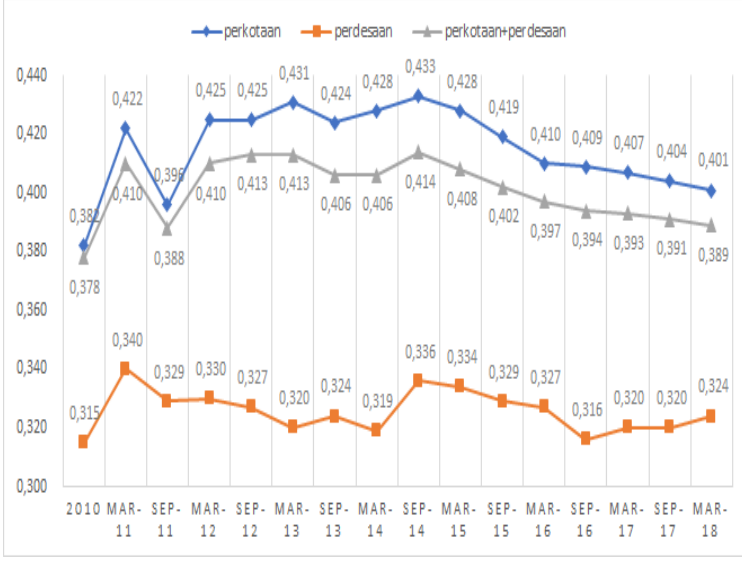

Gambar 2. Perkembangan Gini Ratio Sumber : BPS dari Susenas

Untuk menurunkan kemiskinan pada tingkat yang lebih signifikan dan menurunkan tingkat ketimpangan pengeluaran penduduk perdesaan, maka diperlukan kebijakan pengalokasian dan pemanfaatan dana desa yang lebih mampu membatu menurunkan kemiskinan dengan program-program yang langsung terasa manfaatnya bagi masyarakat miskin. Untuk itu pada 2018 Pemerintah mengeluarkan program yang bertujuan untuk mengurangi kemiskinan dan ketimpangan di desa yaitu Padat Karya Tunai (PKT) Dana Desa. Menurut Buku Pedoman Umum Padat Karya Tunai di Desa 
2018, tujuan dari skema baru ini untuk menciptakan lapangan kerja, meningkatkan pendapatan dan daya beli masyarakat, dan mendorong pertumbuhan ekonomi di pesedaan.

Prinsip dari program padat karya yaitu dilaksanakan secara swakelola, dengan lebih mengutamakan tenaga kerja dan bahan baku setempat serta upah diberikan secara harian/ mingguan. Walaupun saat ini angka pengangguran diperdesaan lebih kecil dari pada di perkotaan saat ini, tapi jumlah angka pengangguran di perdesaan tergolong masih cukup tinggi yaitu pada angka 4,01 persen. Untuk itu, program padat karya yang akan menyedot banyak tenaga kerja sangat dibutuhkan untuk mempercepat mengurangi angka pengangguran. Menurut penelitian Fito (2015), faktor-faktor penyebab pengangguran di desa adalah pendidikan yang rendah, banyaknya anak-anak yang putus sekolah, tidak memiliki keterampilan khusus dan keterbatasan/ minimnya lapangan pekerjaan di desa. Dana Desa diharapkan mampu untuk mengatasi permasalahan yang dihadapi tersebut.

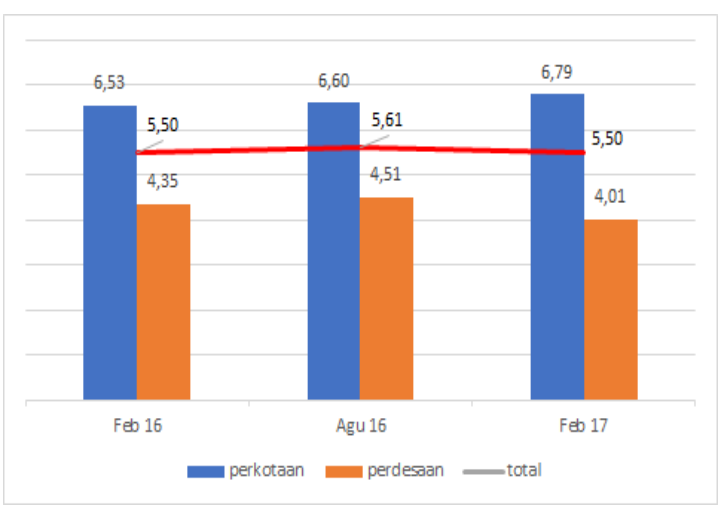

Gambar 3. Angka Pengangguran Sumber : DJPK Kemenkeu

Penelitian terdahulu terkait PKT Dana Desa pernah dilakukan oleh beberapa peneliti. Penelitian yang dilakukan oleh Herdiyana (2019) menunjukkan Program PKT tidak dapat dilaksanakan terhadap pedesaan yang sudah mandiri dan maju karena fasilitas infrastruktur sudah tersedia dan memadai sehingga tidak efektif apabila tetap dilaksanakan.

Penelitian berikutnya dilakukan oleh Budiasa, dkk (2019) merekomendasikan apabila implementasi kebijakan PKT di Desa ingin lebih terlaksana dengan baik maka harus melaksanakan kegiatan prioritas, swakelola, pembayaran upah serta keterlibatan masyarakat. Penelitian lainnya dilakukan oleh Dian dan Ma'ruf (2019) menunjukkan pemberdayaan masyarakat Desa Plandaan melalui Program Padat Karya Tunai berjalan dengan baik namun upah belum sesuai dengan aturan dan kemoloran pelaksanaan.

Temuan awal pelaksanaan PKT Dana Desa di
Jawa Timur adalah PKT belum dapat dilaksanakan dengan optimal karena terkendala masalah perencanaan di APBDes dan kurangnya tingkat kapasitas aparatur desa. Tingkat kapasitas aparatur desa tidak hanya menjadi permasalahan di Jawa Timur saja, hampir diseluruh daerah khususnya di daerah luar jawa mengalami permasalahan yang sama. Seperti hasil penelitian yang dilakukan oleh Aminah dan Sutanto (2018) di mana kapasitas aparatur desa tergolong cukup namun belum optimal mendukung penyelenggaraan desa.

Selain itu perilaku aparat desa yang masih menganggap bahwa dana desa itu uang kepala desa dan perangkat menjadi persoalan sendiri dalam pelaksanaan dana desa dan PKT Dana Desa khususnya. Kewenangan yang terlalu besar dari Kepala Desa dalam praktiknya sering dimanfaatkan oleh kepala desa untuk korupsi (Herdiana, 2019). Untuk itu diperlukan pengawasan dari masyarakat agar program kegiatan yang telah disepakati dalam Musrenbang Desa dapat dilaksanakan dengan baik dan tentunya dapat memberikan kesejahteraan kepada masyarakat desa.

Padat Karya merupakan salah satu bentuk Community Driven Development (CDD), yaitu pengembangan masyarakat yang menekankan pada kontrol komunitas terhadap pengambilan keputusan dan sumber daya investasi (PKN-STAN, 2018). Menurut Nagamatsu (2014), cash for work (CfW) adalah suatu metode untuk membantu korban yang terdampak bencana alam dengan cara mengikutsertakan dalam berbagai macam pekerjaan yang mencakup rekontruksi dan pemulihan paska bencana, serta membayar upah. Oleh sebab itu, masyarakat diharapkan terlibat langsung dalam pembangunan dengan mengoptimalkan sumber daya daerah yang ada.

Negara yang melaksanakan CDD biasanya adalah negara berkembang seperti halnya Indonesia. Negara berkembang lainnya yang melaksanakan CDD antara lain India dengan kegiatan District Poverty and Initiative Program atau Honduras dengan Honduras Sosial. Program CDD di India diperuntukan untuk peningkatan akses infrastruktur dan konsumsi sedangkan di Honduras diperuntukkan untuk akses infrastruktur dan pemberdayaan masyarakat (SDM).

Program CDD pada umumnya berhasil meningkatkan akses terhadap infrastruktur khususnya pendidikan dan kesehatan. Namun demikian, peningkatan akses tesebut tidak selalu meningkatkan perekonomian dan sumber daya manusia di daerah tersebut. Faktor yang menyebabkan biasanya kesalahan dalam penentuan target penerima dan luasan cakupan dari program tersebut.

Untuk itu, tujuan dari penelitian ini adalah untuk mengetahui implementasi pelaksanaan 
program PKT Dana Desa dan untuk mengetahui kendala dalam pelaksanaan program PKT Dana Desa di Kabupaten Pasuruan dan Kabupaten Probolinggo.

\section{METODE}

Penelitian ini merupakan penelitian kualitatif dengan menggunakan teknik triangulasi untuk validasi data yaitu observasi, wawancara mendalam dan studi literatur. Triangulasi merupakan proses menguji keabsahan data yang memanfaatkan sesuatu di luar data untuk keperluan pengecekan data atau pembanding data (Meleong, 2017). Pendekatan yang digunakan dalam penelitian ini adalah pendekatan studi kasus. Adapun dalam (Creswell 2015). Setelah mendapatkan data dari studi literatur, selanjutnya penulis melakukan observasi langsung ke desa. Selain itu penulis juga melakukan wawancara langsung dengan beberapa orang perwakilan dari Dinas Pemberdayaan Masyarakat Desa, Perangkat Desa, dan Masyarakat Desa.

Obyek observasi dalam penulisan kajian ini dilakukan di salah satu desa yang di Kab. Pasuruan, dan Kab. Probolinggo Prov. Jawa Timur. Kriteria desa adalah desa dengan kategori desa tertinggal dan/atau desa sangat tertinggal dengan jumlah penduduk miskin tinggi yang ada dalam data Indeks Desa Membangun dari Kementerian Desa, Pembangunan Daerah Tertinggal dan Transmigrasi.

Dalam kajian ini adalah dua desa yakni Desa Gunung Tugel Kabupaten Probolinggo dan Desa Kalirejo Kabupaten Pasuruan. Pemilihan obyek kajian didasarkan atas pertimbangan: kondisi demografi dan geografi desa yang tersebar di wilayah Jawa Timur; aspek tipologi desa dengan pendekatan desa tertinggal dan desa sangat tertinggal dengan jumlah penduduk miskin tinggi di diwilayah Jawa Timur; dan budaya dan kearifan lokal dari masing-masing desa di tiap kabupaten yang berbeda satu dengan lainnya;

\section{Hasil dan Pembahasan}

Bagian ini akan membahas beberapa poin yang menjadi jawaban terhadap pertanyaan penelitian di atas. Beberapa poin tersebut adalah; Kebijakan PKT Dana Desa; Aspek sosial dan keuangan desa; Perencanaan dan pelaksanaan PKT dana desa, serta; Kendala pelaksanaan PKT dana desa.

\section{A. Kebijakan PKT Dana Desa}

Program PKT Dana Desa bertujuan untuk penciptaan lapangan kerja melalui kegiatan pembangunan secara swakelola dan padat karya tunai, memupuk rasa kebersamaan, gotong royong dan partisipasi masyarakat Desa, meningkatkan kualitas dan kuantitas pemberdayaan masyarakat
Desa, mewujudkan peningkatan akses masyarakat miskin, perempuan, anak, dan kelompok marginal kepada pelayanan dasar, dengan berbasis pendekatan pemberdayaan masyarakat, menekan jumlah penganggur, setengah penganggur dan masyarakat miskin, dan membangkitkan kegiatan sosial ldan ekonomi di Desa.

Sasaran program PKT Dana Desa berdasarkan Pedoman Umum Pelaksanaan Padat Karya Tunai 2018 yang dikeluarkan oleh Kementerian Koordinator Pembangunan Manusia dan Kebudayaan dan Kementerian PPN/Bappenas adalah 1) Penganggur, yaitu penduduk yang tidak mempunyai pekerjaan dan sedang mencari pekerjaan, 2) Setengah Penganggur, yaitu Penduduk yang bekerja di bawah jam kerja normal $(<35$ jam seminggu) dan masih mencari pekerjaan atau masih bersedia menerima pekerjaan, 3) Penduduk miskin, yaitu penduduk yang memiliki rata-rata pengeluaran perkapita perbulan di bawah garis kemiskinan, dan 4) Stunting, yaitu penduduk yang memiliki balita bermasalah gizi. Sedangkan prinsip pelaksanaan PKT dana desa yaitu:

1) Inklusif

Perencanaan dan pelaksanaan kegiatan Padat Karya Tunai di Desa perlu disusun berdasarkan kebutuhan masyarakat dengan mempertimbangkan aspek tenaga kerja (penganggur, setengah penganggur dan masyarakat marginal/miskin), kondisi geografis, sosial, budaya dan ekonomi serta mempertahankan daya dukung dan keseimbangan lingkungan.

2) Partisipatif dan Gotong Royong

Pelaksanaan kegiatan Padat Karya Tunai di Desa berdasarkan asas "DARI, OLEH dan UNTUK masyarakat". Pemerintah berperan sebagai fasilitator yang mendampingi pemerintah Desa, BPD dan masyarakat Desa untuk melaksanakan pembangunan Desa secara partisipatif dan gotong royong.

\section{3) Transparan dan Akuntabel}

Pelaksanaan kegiatan Padat Karya Tunai di Desa dilakukan dengan mengutamakan prinsip transparan dan akuntabel baik secara moral, teknis, legal maupun administratif kepada semua pihak.

4) Efektif

Kegiatan Padat Karya Tunai di Desa harus memiliki dampak positif terhadap produktifitas, kesejahteraan masyarakat, dan pertumbuhan perekonomian.

5) Swadaya

Kegiatan Padat Karya Tunai di Desa dilaksanakan dengan mendorong adanya sumbangan dana, tenaga, material, dan asset bergerak dan/atau tidak bergerak dari warga Desa yang berkecukupan.

6) Prioritas

Kegiatan Padat Karya Tunai di Desa 
dilaksanakan dengan mendahulukan kepentingan sebagian besar masyarakat Desa yang berdampak pada terciptanya lapangan kerja, teratasinya kesenjangan, dan terentaskannya warga miskin.

7) Swakelola

Kegiatan Padat Karya Tunai di Desa dilaksanakan secara mandiri oleh Desa dengan mendayagunakan tenaga kerja, bahan material, serta peralatan dan teknologi sederhana yang ada di Desa.

\section{8) Keberlanjutan}

Kegiatan Padat Karya Tunai di Desa dilaksanakan dengan memastikan adanya rencana pengelolaan dalam pemanfaatannya, pemeliharaan, perawatan dan pelestariannya.

9) Disepakati dalam musyawarah desa

Kegiatan Padat Karya Tunai di Desa dibahas dan disepakati dalam musyawarah desa yang diselenggarakan berdasarkan asas kesamaan dan kesetaraan bagi setiap peserta musyawarah Desa melalui hak bicara, hak berpendapat dan hak bersuara dalam mencapai kemufakatan bersama.

10) Berbasis Kewenangan Lokal Desa dan Hak Asal Usul

Kegiatan Padat Karya Tunai di Desa yang pembiayaannya bersumber dari APBDesa harus menjadi bagian dari Daftar Kewenangan Desa berdasarkan Hak Asal Usul dan Kewenangan Lokal Berskala Desa.

\section{1) Kewenangan yang ditugaskan kepada desa}

Kegiatan Padat Karya Tunai di Desa yang pembiayaannya bersumber dari Non APBDesa diatur sesuai dengan ketentuan peraturan perundang-undangan.

12) Penentuan Upah

Batas Bawah dan Batas Atas Upah/ Hari Orang Kerja (HOK) ditentukan berdasarkan hasil kesepakatan musyawarah desa mengacu pada Peraturan Bupati/Walikota. Adapun batas atas upah/HOK dibawah upah minimum provinsi. besaran upah/HOK lebih lanjut akan diatur oleh peraturan bupati/walikota.

Kerangka pikir program PKT Dana Desa yaitu ditujukan bagi masyarakat kurang mampu, menciptakan kegiatan yang berdampak pada peningkatan pendapatan (income generating activities) tanpa sepenuhnya menggantikan pekerjaan yang lama, merupakan kesempatan kerja sementara. Selanjutnya mekanisme dalam penentuan upah dan pembagian upah dibangun secara partisipatif dalam musyawarah desa, berdasarkan rencana kerja yang disusun sendiri oleh Desa sesuai dengan kebutuhan lokal, dan difokuskan pada pembangunan sarana prasarana perdesaan atau pendayagunaan sumberdaya alam secara lestari berbasis pemberdayaan masyarakat.

Pelaksanaan Kegiatan PKT Dana Desa bersifat swakelola dengan tetap dimungkinkan adanya pengadaan barang/jasa sesuai ketentuan peraturan perundang-undangan. PKT Dana Desa mengutamakan penggunaan tenaga kerja dan material/bahan baku yang berasal dari warga Desa setempat, sehingga bisa menyerap tenaga kerja dan memberikan pendapatan bagi warga Desa yang terlibat di kegiatan tersebut. Upah kerja diberikan secara langsung kepada warga Desa yang terlibat dalam kegiatan PKT Dana Desa. Upah kerja dimaksud diberikan secara harian, namun apabila tidak memungkinkan dapat diberikan secara mingguan.

Hari Orang Kerja (HOK) merupakan penghitungan banyaknya upah yang harus dibayar untuk tenaga kerja yang digunakan dalam satu kegiatan. Sesuai SKB empat menteri, HOK dalam penggunaan Dana Desa dihitung sebesar 30 persen dari biaya kegiatan untuk membayar upah masyarakat, dengan ketentuan sebagai berikut:

a) Jumlah 30 persen untuk pembayaran HOK dihitung dari jumlah Dana Desa yang digunakan untuk membiayai kegiatan pembangunan Desa;

b) Jumlah 30 persen untuk pembayaran HOK mencakup pembayaran tenaga kerja untuk mengangkut bahan material untuk bangunan, penyiapan lokasi bangunan, dan pelaksanaan kegiatan pembangunan;

c) Jumlah tenaga kerja mencakup tenaga kerja ahli, pembantu tenaga kerja ahli serta tenaga masyarakat Desa setempat yang ditetapkan sebagai sasaran Padat Karya Tunai di Desa; dan

d) Besaran upah tenaga kerja dihitung berdasarkan batas bawah dan batas atas upah tenaga kerja yang ditentukan berdasarkan hasil kesepakatan musyawarah Desa dengan mengacu pada peraturan bupati/walikota tentang besaran upah tenaga kerja (Hari Orang Kerja/HOK).

Pemenuhan 30 persen HOK dari keseluruhan alokasi kegiatan pembangunan Desa bersifat wajib dan harus dilaksanakan oleh seluruh Desa penerima dana desa. Pelaksanaannya dalam APBDes adalah sebagai berikut:

a) Bagi desa yang telah menetapkan APBDesa sebelum terbitnya SKB 4 Menteri tentang Penyelarasan Dan Penguatan Kebijakan Percepatan Pelaksanaan UU No 6 Tahun 2014 Tentang Desa diwajibkan; a) Desa merevisi APBDesa untuk menyesuaikan pemenuhan HOK minimal sebesar 30 persen; b) Jika tidak mencapai 30 persen HOK, maka Desa melakukan melakukan penyesuaian perhitungan RAB dan desain teknis kegiatan.

b) Bagi Desa yang belum menetapkan APBDesa sampai dengan diterbitkannya SKB 4 Menteri tentang Penyelarasan Dan Penguatan Kebijakan Percepatan Pelaksanaan UU No 6 Tahun 2014 
Tentang Desa agar menyusun RAB (Rancangan Anggaran Biaya) dan Desain Teknis kegiatan pembangunan untuk memenuhi minimal 30 persen HOK dari keseluruhan alokasi kegiatan pembangunan Desa.

Penggunaan dana desa dilakukan secara swakelola, di mana dana desa sejak tahap perencanaan dan pelaksanaan kegiatan dilakukan secara mandiri oleh desa dan memungkinkan untuk tidak dikontrakkan kepada pihak ketiga/kontraktor. Pelaksanaan kegiatan PKT yang menggunakan Dana Desa dilakukan oleh Tim Pengelola Kegiatan (TPK) dan dalam penetapan harga satuan kegiatan/HOK mengacu pada peraturan Bupati/Walikota Tentang Harga Satuan Biaya setempat.

Jenis kegiatan PKT Dana Desa yang bisa dilaksanakan oleh desa antara lain, pembangunan dan/atau rehabilitasi sarana prasarana perdesaan sesuai dengan daftar kewenangan Desa. Jenis kegiatannya berupa perbaikan alur sungai dan irigasi, pembangunan dan/atau perbaikan jalan, dan jembatan skala Desa, serta tambatan perahu.

Pilihan kegiatan berikutnya yaitu pemanfaatan lahan untuk meningkatkan produksi, termasuk di kawasan hutan, antara lain, Pertanian, Perhutanan, Perkebunan, Peternakan, dan Perikanan. Selanjutnya kegiatan produktif lainnya, berupa pariwisata, eEkonomi kreatif, pengembangan potensi ekonomi lokal dengan mendorong kewirausahaan, pengelolaan hasil produksi pertanian, dan pengelolaan usaha jasa dan industri kecil.

Kegiatan PKT juga bisa dalam bentuk pemberdayaan masyarakat yaitu pengelolaan sampah, pengelolaan limbah, pengelolaan lingkungan pemukiman, pengembangan energi terbarukan, serta penyediaan dan pendistribusian makanan tambahan bagi anak (bayi dan balita). Selain itu juga dapat digunakan untuk kegiatan yang tidak berhubungan langsung dengan penyelesaian pekerjaan fisik bangunan, tetapi mendukung keberhasilan pelaksanaan pekerjaan fisik tersebut, misalnya mengemudikan kendaraan pengangkut bahan dan alat kerja.

Ketentuan refocusing kegiatan pembangunan Desa yang dibiayai dana desa untuk memastikan 30 persen dari biaya kegiatan pembangunan desa digunakan untuk membayar upah masyarakat dilakukan dengan ketentuan sebagai berikut: (1) Refocusing kegiatan pembangunan Desa dilakukan dengan berdasarkan ketentuan tentang penetapan prioritas penggunaan dana desa 2018 sebagaimana diatur berdasarkan Peraturan Menteri Desa, Pembangunan Daerah Tertinggal dan Transmigrasi No 19 Tahun 2017 tentang Penetapan Prioritas Penggunaan Dana Desa Tahun 2018; (2) Jenis kegiatan refokusing kegiatan pembangunan yang diprioritaskan sesuai ketentuan Peraturan Menteri Desa, Pembangunan Daerah Tertinggal dan Transmigrasi Nomor 19 Tahun
2017 tentang Penetapan Prioritas Penggunaan Dana Desa Tahun 2018 Pasal 4 sebagai berikut: a) Prioritas Penggunaan Dana Desa untuk membiayai pelaksanaan program dan kegiatan di bidang pembangunan Desa dan pemberdayaan masyarakat Desa; b) Prioritas penggunaan Dana Desa diutamakan untuk membiayai pelaksanaan program dan kegiatan yang bersifat lintas bidang; c) Program dan kegiatan sebagaimana dimaksud pada ayat (2) antara lain bidang kegiatan produk unggulan Desa atau kawasan perdesaan, BUM Desa atau BUM Desa Bersama, embung, dan sarana olahraga Desa sesuai dengan kewenangan Desa; d) Pembangunan sarana olahraga Desa sebagaimana dimaksud pada ayat (3) merupakan unit usaha yang dikelola oleh BUM Desa atau BUM Desa Bersama; e) Prioritas penggunaaan Dana Desa sebagaimana dimaksud pada ayat (1) wajib dipublikasikan oleh Pemerintah Desa kepada masyarakat Desa di ruang publik yang dapat diakses masyarakat Desa; (3) Dalam hal rencana kegiatan pembangunan desa tahun 2018 dibuktikan belum memuat 30\% dana desa digunakan untuk membayar upah tenaga kerja, wajib dilakukan refokusing pada 3 (tiga) sampai 5 (lima) jenis kegiatan; (4) Refokusing penggunaan dana desa untuk padat karya tunai tetap berpedoman pada permendesapdtt no. 19 tahun 2017 tentang penetapan prioritas penggunaan dana desa tahun 2018; (5) Refocusing diarahkan kepada kegiatan-kegiatan yang termasuk ke dalam 4 (empat) program prioritas nasional pembangunan desa yaitu: prudes/prukades, bumdesa/bumdesa bersama, embung dan sarana olah raga desa.

\section{B. Aspek Sosial dan Keuangan Desa}

Desa Gunung Tugel terletak di Kecamatan Bantaran, Kabupaten Probolinggo, Provinsi Jawa Timur memiliki luas wilayah $919.651 \mathrm{Ha}$ yang didalamnya terdapat hutan milik perhutani dengan luas 202 Ha. Desa dengan penduduk 2045 orang laki-laki dan 2320 perempuan, hampir sebagian besar mata pencahariannya ada dari sektor pertanian dan peternakan sebagai petani dan buruh tani (1.106 orang). Selain itu sebagian kecil penduduknya mengandalkan mata pencahariannya dari berdagang, sopir, PNS dan pensiunan.

Potensi Desa Gunung Tugel salah satunya adalah penghasil ternak baik sapi, kambing, maupun unggas. Kondisi perekonomian masyarakat yang terbilang rendah disebabkan minimnya pemanfaatan sumber daya alam dan minimnya sumber daya manusia. Fasilitas dan akses untuk mendukung masyarakat dalam bertani dan berdagang sangatlah minim. Jalan penghubung antar desa dan akses menuju lahan pertanian sangat sempit dan hanya bisa dilewati kendaraan roda dua di musim kemarau saja. Jika musim penghujan tiba maka dengan curah hujan yang tinggi akan membuat becek. 
Sebagaian besar pemuda Desa Gunung Tugel menggantungkan kehidupannya dengan bekerja di kota besar. Sehingga tidak banyak yang ikut serta dalam kegiatan PKT Dana Desa. Unsur pemuda masih sangat apatis dengan rencana pembangunan di desa, bahkan cenderung pada kegiatan yang negatif serta aktivitas yang menuju pada kekerasan. Sehingga tingkat pencurian utamanya hewan ternak di desa masih sangat tinggi.

Pendapatan Desa Gunung Tugel dalam APBDes Tahun 2018 adalah sebesar Rp1.826.607.200,terdiri dari Dana Desa sebesar Rp1.373.265.000,-, Alokasi Dana Desa (ADD) sebesar Rp427.914.700, dan Bagi Hasil Pajak (PDRD) sebesar Rp25.427.500,- Sampai saat ini Desa Gunung Tugel belum memiliki Pendapatan Asli Desa (PADes) dalam APBDes-nya, hal ini disebabkan BUMDes baru dibentuk pada tahun 2017 dengan usaha utamanya mengembangkan destinasi wisata kampung buah.

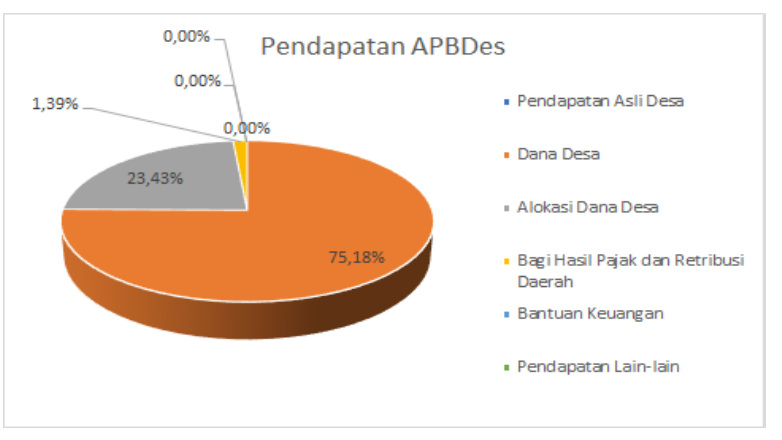

Gambar 4.

Pendapatan APBDes Desa Gunung Tugel Tahun 2018 Sumber: APBDes Gunung Tugel (diolah)

Belanja Desa dalam APBDes sebagian besar digunakan untuk bidang Penyelenggaraan Pemerintahan Desa sebesar Rp422.916.570,- atau 24,09 persen dan bidang Pelaksanaan Pembangunan Desa sebesar Rp1.142.281.100.- atau 65,08 persen dari jumlah Belanja sebesar Rp1.755,079,070,. Sisanya sebesar 10,83 persen digunakan untuk bidang Pembinaan Kemasyarakatan Desa, Pemberdayaan Masyarakat Desa dan tak terduga.

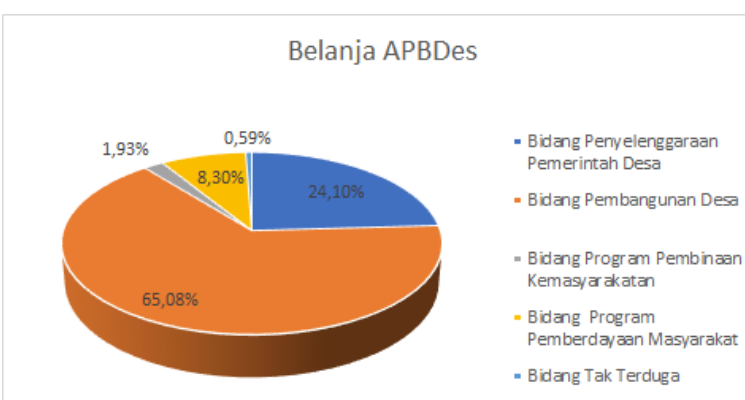

Gambar 5 .
Belanja APBDes Desa Gunung Tugel Tahun 2018 Sumber: APBDes Gunung Tugel (diolah)

Apabila belanja desa dibagi perjenis belanjanya maka belanja pegawai mendapatkan porsi sebesar 16,01 persen, belanja barang dan jasa sebesar 26,36 persen dan sisanya sebesar 57,63 persen untuk diluar dua belanja tersebut. Pada tahun 2018 terdapat penyertaan modal desa kepada BUMDes sebesar Rp75.000.000,- dan penghasilan tetap (Siltap) Kepala Desa dan Perangkat Desa sebesar Rp230.400.000,-- atau sebesar 53,84 persen dari Alokasi Dana Desa.

Selanjutnya, Desa Kalirejo adalah salah satu desa di wilayah kecamatan Kraton, Kabupaten Pasuruan. Penduduk Desa Kalirejo ada sebanyak 7.617 jiwa. Mayoritas mata pencaharian masyarakatnya adalah buruh tani dengan 175 jiwa, selebihnya pegawai swasta ada 133 jiwa, nelayan dan petani dengan jumlah 65 jiwa, pegawai negeri ada 11 jiwa, dan TNI/Polri ada 7 jiwa.

Desa Kalirejo mempunyai 1 SD Negeri, 2 Madrasah Ibtidaiyah, 4 Madrasah Diniyah, dan 5 Taman Pendidikan Qur'an (TPQ). Tingkat pendidikan masyarakat Desa Kalirejo sebagian besar lulusan SD/MI dengan jumlah 1054 orang, kemudian disusul lulusan SMP/MTs sebanyak 147 orang dan SMA/sederajat sebanyak 66 orang.

Pendapatan Desa Kalirejo dalam APBDes Tahun 2018 sebesar Rp2.082.850.000,- terdiri dari PADes sebesar Rp1.500.000,- dan Pendapatan Transfer sejumlah Rp2.081.350.000,-. Sebagian besar pendapatan transfer berasal dari Dana Desa yaitu Rp1.330.199.000,- atau sekitar 63,91 persen dari total pendapatan transfer. Selanjutnya terdapat pendapatan dari ADD sebesar Rp496.669.000, Bagi Hasil Pajak Daerah dan Retribusi Daerah (Bagi Hasil PDRD) sebesar Rp74.482.000,- dan Bantuan Keuangan Kabupaten yaitu sebesar Rp180.000.000,-

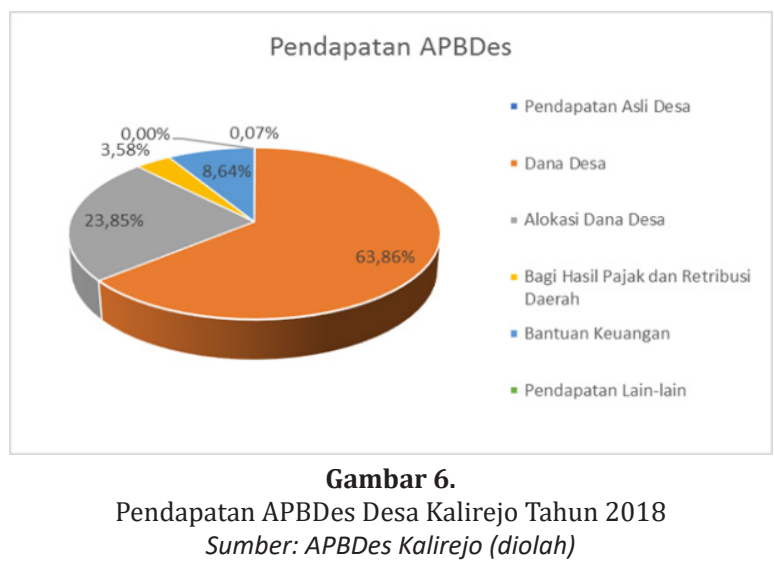

Belanja APBDes Desa Kalirejo tahun 2018 sebesar Rp2.465.545.129,--. Alokasi untuk bidang penyelenggaraan pemerintah adalah sebesar Rp628.011.516,- atau 25,47 persen. Berikutnya bidang pelaksanaan pembangunan desa mendapatkan alokasi terbesar dengan

Implementasi Padat Karya Tunai Dana Desa untuk Masyarakat Miskin di Kabupaten Pasuruan Dan Kabupaten Probolinggo 
Rp1.649.592.613,- atau 66,91 persen. Sisanya untuk bidang pembinaan kemasyarakatan dan pemberdayaan masyarakat dengan porsi alokasi 7,69 persen atau sebesar Rp187.841.000,-
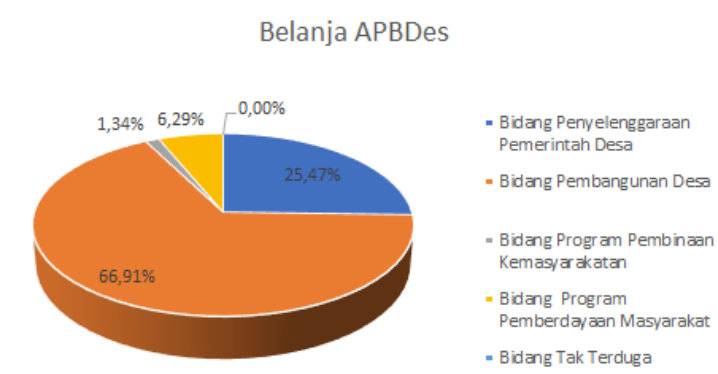

Gambar 7.

Belanja APBDes Desa Kalirejo Tahun 2018 Sumber: APBDes Kalirejo (diolah)

\section{Perencanaan dan Pelaksanaan PKT Dana Desa}

Pelaksanaan PKT Dana Desa pertama kali diimplementasi pada Tahun Anggaran 2018 dengan penggunaan HOK sebesar 30 persen dari total dana desa yang berasal dari bidang pembangunan infrastruktur desa. Kebijakan ini muncul dengan terbitnya SKB 4 Menteri diawal 2018 sehingga terdapat beberapa desa yang sudah menyelesaikan pembahasan dan penetapan APBDes. Untuk desa yang belum menyelesaikan akan menyesuaikan dan untuk desa yang sudah menetapkan akan dilakukan kembali refokusing kegiatan sehingga banyak APBDes yang mengalami keterlambatan penetapan Perdes APBDes.

Sosialisasi pelaksanaan program PKT Dana Desa khususnya untuk HOK 30 persen dilakukan oleh Badan Pemberdayaan Masyarakat Desa (BPMD) dengan bantuan para pendamping. Tetapi dalam pelaksanaanya ada BPMD yang tidak melakukan kegiatan sosialisasi dengan mengundang seluruh perangkat desa dikarenakan keterbatasan dana atau belum dianggarkannya di dalam Dokumen Pengesahan Anggaran (DPA). Seperti yang dilakukan oleh BPMD Kab. Probolinggo yang menggunakan metode lain dengan turun ke desa melalui pendampingan. Sehingga suasana keakraban antara DPMD, pendamping, unsur musyawarah pimpinan kecamatan, dan aparatur desa terjalin dengan baik.

Penentuan kegiatan yang akan dilaksanakan pada tahun bersangkutan dilakukan melalui musrembangdes dengan berbagai metode yang dilakukan antara lain melalui usulan dari beberapa RT/RW/Dusun kemudian dilakukan pemeringkatan berdasarkan urgensinya atau melalui bagi rata untuk semua Dusun. Pelaksanaan penentuan kegiatan yang di danai dari Dana Desa di Desa Gunung Tugel dilakukan melalui usulan dan ditetapkan bergantian antar dusun, karena jumlah dusunnya yang banyak sampai dua belas dusun maka Kepala Desa yang merupakan juga tokoh masyarakat sangat dipatuhi apa yang menjadi kebijakannya.

Belanja APBDes Tahun 2018 pada dua desa sebagian besar digunakan untuk bidang pembangunan desa untuk mendukung program PKT Dana Desa. Untuk itu perlu perencanaan yang baik agar hasilnya dapat bermanfaat secara langsung untuk masyarakat dengan pemilihan kegiatan atau proyek yang benar-benar diperlukan dan menjadi kebutuhan masyarakat desa.

Perencanaan penggunaan Dana Desa telah dilakukan berdasarkan Permendes PDTT No 19 Tahun 2017 tentang Penetapan Prioritas Penggunaan Dana Desa Tahun 2018 di mana perencanaan telah mempertimbangkan kepentingan desa yang mendesak, dibutuhkan dan berhubungan langsung dengan masyarakat, serta mengutamakan prakarsa dan kreativitas masyarakat. Selain itu juga mempertimbangkan keadaan karakteristik desa dan lebih memanfaatkan sumber daya yang ada di desa.

Separuh lebih PKT Dana Desa digunakan untuk membangun jalan rabat beton/paving. Hasil wawancara dengan perangkat desa diperoleh informasi bahwa pembangan jalan merupakan prioritas utama di desa karena selama ini jalan desa masih berupa jalan setapak yang akan sulit dilalui jika musim penghujan dan dengan pembangunan jalan ini akan mempermudah masyarakat desa untuk mengangkut hasil pertanian atau perkebunan dari sawah atau kebun. Selanjutnya diikuti pembangunan drainase/saluran irigasi dan pembangunan talud.

Penggunaan Dana Desa disesuaikan dengan karakteristik desa. Desa yang letaknya di pesisir seperti Desa Kalirejo Kabupaten Pasuruan lebih memprioritaskan untuk tempat tambatan perahu dan tempat pelelangan ikan karena sebagian besar penduduk desanya berprofesi sebagai nelayan. Pembangunan sarana dan prasarana dasar untuk pelayanan publik desa dengan kategori desa sangat tertinggal dan desa tertinggal merupakan salah satu prioritasnya sesuai dengan Permendes PDTT No 19 Tahun 2017.

Sebagian besar pelaksanaan program kegiatan yang menyerap tenaga kerja dari PKT Dana Desa baru dapat dilaksanakan pada bulan Mei, bahkan ada yang bulan Juni 2018. Hal ini disebabkan oleh masih perlu adanya penyesuaian dan refokusing kegiatan untuk mengakomodir HOK 30 persen. Berdasarkan data hasil penelitian pemenuhan HOK untuk Desa Gunung Tugel telah memenuhi HOK dengan 40,10\% sedangkan Desa Kalirejo belum memenuhi karena hanya 28,39 persen. Namun demikian PKT yang ada di Desa Kalirejo jumlahnya melebihi pagu Dana Desa karena dananya berasal dari pendapatan diluar Dana Desa. 


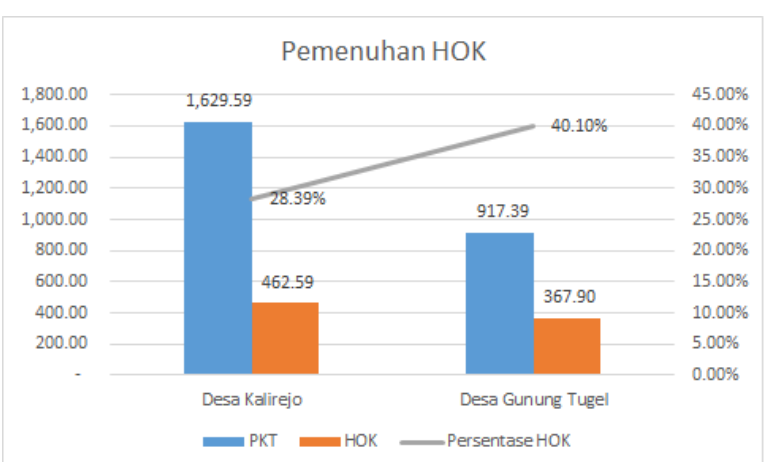

Gambar 8.

Pemenuhan HOK Desa Kalirejo dan Desa Gunung Tugel Sumber : APBDes 2018 (diolah)

Banyak desa yang mengalami kesulitan untuk pemenuhan 30 persen HOK. Hal ini disebabkan oleh jenis kegiatan yang dipilih tidak banyak memerlukan tenaga kerja dan bahkan hanya memerlukan banyak material dan alat berat untuk mengerjakannya seperti yang disampaikan oleh Ketua Tim Pengelola Kegiatan (TPK) Desa Kalirejo. Banyak desa juga tidak memiliki sumber daya material sendiri sehingga perlu mendatangkan dari tempat yang jaraknya cukup jauh. Hal ini terjadi untuk desa yang daerahnya sebagian besar pesisir (seperti Desa Kalirejo) atau juga juga kendala transportasi khususnya untuk bahan material.

Penentuan upah tenaga kerja dalam pelaksanaan PKT Dana Desa mengikuti tarif upah lokal. Upah tenaga kerja di Provinsi Jawa Timur khusus desa tersebut masing-masing sebesar Rp60.000,- untuk pekerja, Rp80.000,- untuk tukang dan Rp100.000,- untuk kepala tukang. Tujuan program PKT Dana Desa yaitu untuk meningkatkan pendapatan sebagaian besar masyarakat desa khususnya pengangguran. Mereka diikut sertakan dalam kegiatan ini dan mereka diberikan upah secara harian/mingguan.

Jumlah tenaga kerja yang terserap dalam program ini rata-rata 55 warga penduduk setempat, tidak memiliki pekerjaan dan miskin. Pemilihan warga yang ikut serta dalam kegiatan tersebut dilakukan secara musyawarah dan masing-masing kegiatan melibatkan warga dusun tempat kegiatan itu dilaksanakan dengan dipimpin oleh Kepala Rukun Warga atau Kepala Dusun.

Apabila tidak terdapat tukang di desa tersebut maka bisa menggunakan tenaga tukang dari desa tetangga. Untuk desa dengan wilayah pesisir sulit seperti Desa Kalirejo kesulitan untuk mencari tukang atau pekerja karena sebagian besar penduduk desa berprofesi sebagai nelayan. Dalam pelaksanaan program PKT Dana Desa melibatkan juga Babinsa dan Babinkamtibmas untuk memitigasi kemungkinan resiko. Selain itu juga melibatkan Polhut untuk desa yang memiliki wilayah hutan lindung seperti Desa Gunung Tugel Kabupaten Probolinggo.
Berdasarkan hasil wawancara dengan beberapa masyarakat desa yang hadir di Balai Desa Kalirejo dan Gunung Tugel, Sambutan masyarakat desa terhadap adanya Dana Desa dan PKT Dana Desa sangat positif dan berharap Dana Desa terus ada dan terus berlanjut. Masyarkat desa juga berharap jumlah Dana Desa bisa lebih besar lagi kedepannya. Dana Desa bisa langsung menyelesaikan masalah pembangunan di desa yang dahulu sulit untuk mengusulkan pembangunan di desa dan bisa membangun apa yang menjadi prioritas dan dibutuhkan langsung oleh masyarakat desa.

\section{Kendala Pelaksanaan PKT Dana Desa}

Berdasarkan observasi lapangan dan diskusi dengan perangkat desa serta masyarakat desa, terdapat beberapa kendala yang dihadapi dalam pelaksanaan program PKT Dana Desa antara lain :

\section{1) Kencenderungan Berkurangnya Semangat Gotong Royong}

Salah satu budaya yang dimiliki oleh masyarakat Indonsesia dan selalu dilakukan secara turun temurun yaitu gotong royong. Apabila ada pekerjaan di desa selalu dilakukan melalui kerja bakti secara gotong royong. Semua warga secara sukarela ikut serta membantu mengerjakan perbaikan jalan atau selokan. Saat ini setelah adanya PKT Dana Desa gotong royong mulai menurun, sedikit-sedikit warga menanyakan apakah ada upahnya. Seharusnya program PKT Dana Desa ini mampu menjadi stimulus untuk pengerjaan kegiatan yang ada di desa. Tidak semua kegiatan yang ada di desa harus dinilai dengan uang.

\section{2) Domisili Pendamping Desa Yang Jauh dari Desa}

Pendamping desa merupakan salah satu aktor penting dalam suksesnya pelaksanaan Dana Desa pada umumnya dan program PKT Dana Desa pada khususnya. Pendampingan kepada desa perlu intensif dilakukan mengingat sebagian aparat desa selaku pelaksana kegiatan terbilang masih minim pendidikannya dan umurnya sudah banyak yang paruh baya. Pendamping desa domisilinya banyak yang tidak berada di desa tersebut sehingga mempersulit jika suatu saat diperlukan/dibutuhkan. Pendamping Desa juga banyak yang mengeluhkan terkait honor yang diterimanya. Honor tersebut dirasa tidak mencukupi untuk biaya operasional pendampingan yang letak desa atau dusunnya sangat jauh.

\section{3) Terlalu Banyaknya Regulasi Yang Harus Dipahami.}

Kementerian yang terlibat dalam pelaksanaan Dana Desa ada tiga yaitu Kementerian Desa PDDT, Kementerian Dalam Negeri dan Kementerian Keuangan. Tidak jarang masing-masing kementerian tersebut mengeluarkan peraturan menteri dalam rangka pelaksanaan kegiatan PKT 
Dana Desa. Beberapa isi dari peraturan tersebut ada yang berbenturan bahkan ada beberapa kali yang mengalami perubahan peraturan. Hal ini yang membuat kesulitan untuk memahami dan melaksanakan aturan tersebut khususnya bagi aparat desa dan tim pelaksana kegiatan yang ratarata pendidikannya rendah dan sudah lanjut usia.

\section{4) Jumlah Tenaga Ahli Yang Kurang}

Penyusunan rencana anggaran kegiatan dan pelaksanaan kegiatan fisik memerlukan ahli yang mengerti dan mampu untuk mendampingi desa. Dalam pelaksanaannya Tenaga Ahli (TA) jumlahnya terbatas, TA infrastruktur biasanya jumlahnya hanya satu untuk satu kabupaten lain halnya TA pemberdayaan yang jumlahnya lebih banyak. Hal ini ironi karena sebagian besar Dana Desa digunakan untuk bidang pembangunan yang jumlahnya lebih dari 60 persen dari total anggaran di desa. Ini akan menjadi persoalan apabila jumlah desa yang ada dalam satu kabupaten jumlahnyanya banyak.

\section{5) Karakteristik Wilayah}

Karakteristik wilayah menjadi kendala lain dalam pelaksanaan program PKT Dana Desa. Kebijakan ini dikeluarkan untuk dilaksanakan secara keseluruhan oleh Desa yang menerima Dana Desa. Kendala yang akan dihadapi oleh desa yang memiliki karakteristik wilayah yang sulit akan lebih banyak. Demikian juga untuk desa yang sebagaian besar wilayah perairan akan membuat biaya transportasi jauh lebih mahal karean pekerjaan proyek memerlukan bantuan alat berat. Kateristik ini yang akan membuat kesulitan desa untuk memenuhi ketentuan 30 persen HOK.

Kedepan untuk pelaksanaan PKT Dana Desa sebaiknya Pemerintah tidak perlu diberikan batasan terhadap HOK. Biarkan kepada desa untuk menentukan sesuai dengan kondisi masingmasing desa. Pemerintah cukup mendorong desa untuk menggunakan mekanisme swakelola dalam pembangunan infrastruktur di desa dengan melibatkan sebanyak-banyaknya tenaga kerja lokal yang termasuk penduduk miskin. Untuk tenga kerja ahli tetap diutamakan warga desa setempat walaupun tidak termasuk penduduk miskin. Pemerintah juga tetap hadir melalui pendamping desa membantu dalam penyusunan sasaran dari PKT.

\section{KESIMPULAN}

Berdasarkan hasil penelitian diatas dapat simpulkan bahwa pelaksanaan PKT Dana Desa berjalan dengan baik dan memberikan manfaat kepada masyarakat miskin dengan minimal 55 tenaga kerja yang bisa terserap dalam setiap kegiatan. Rata-rata pemenuhan HOK 30 persen telah dilakukan oleh Desa melalui refokusing atau perubahan Rancangan Anggaran Belanja (RAB) kegiatan.
Penulis menyampaikan beberapa masukan untuk mengatasi kendala yang dihadapi dalam pelaksanaan PKT Dana Desa, pertama Pemerintah perlu mempertahankan program PKT Dana Desa ini karena sangat bermanfaat untuk masyarakat desa dalam rangka meningkatkan pendapatan masyarakat secara langsung khususnya yang menganggur atau setengah menganggur. Kedua, kedepan batasan HOK 30 persen tidak lagi menjadi patokan dan memberikan kebebasan kepada desa untuk menggunakan Dana Desa dengan metode swakelola. Semoga penelitian ini dapat memberikan manfaat khususnya kepada Pemerintah Pusat dalam menentukan kebijakan PKT Dana Desa kedepannya. Selain itu, dapat memberikan masukan Pemerintah Desa dalam pelaksanaan PKT Dana Desa dan HOK pada khususnya. Penelitian ini memiliki keterbatasan di mana subjek penelitian yang digunakan hanya dua desa di Provinsi Jawa Timur. Oleh sebab itu, kedepannya dapat dikembangkan lagi dengan subjek penelitian yang lebih banyak serta lebih mewakili regional wilayah Indonesia. Selain itu, agar dapat menggunakan metode kuantitatif sehingga terlihat dampak dari PKT Dana Desa terhadap masyarakat miskin.

\section{UCAPAN TERIMA KASIH}

Penulis menyampaikan ucapan terima kasih yang tak terhingga kepada Dinas Pemberdayaan Masyarakat Desa Kabupaten Probolinggo, Dinas Pemberdayaan Masyarakat Desa Kabupaten Pasuruan, Perangkat Desa Gunung Tugel dan Perangkat Desa Desa Kalirejo serta teman-teman fungsional Analis Keuangan Pusat dan Daerah pada Direktorat Dana Transfer Umum yang telah membantu dalam penulisan ini.

\section{Daftar Pustaka}

Aminah, Sitti, and Hari Prasetyo Sutanto. 2018. "Analisis Tingkat Kapasitas Aparatur Pemerintah Desa Di Kabupaten Bogor." Matra Pembaruan 2(3): 149-60. http://doi. org/10.21787/mp.2.3.2018.149-160.

Anshari, Khairullah. 2017. "Indonesia's Village Fiscal Transfers: A Fiscal Decentralisation Review." Jurnal Studi Pemerintahan 8(3). http://dx.doi. org/10.18196/jgp.2017.0050.296-326

Ardiana, I Putu Eva, and I Ketut Tjukup. 2018. “Kajian Yuridis Prioritas Penggunaan Dana Desa Dalam Kaitannya Dengan Otonomi Desa Berdasarkan Undang-Undang Nomor 6 Tahun 2014 Tentang Desa." Kertha Negara: Journal Ilmu Hukum 6(02): 1-18. https://ojs.unud.ac.id/index. php/Kerthanegara/article/view/38804

Budiasa, Anak Agung Gde Rai, A.A. Gede Raka, and I Made Mardika. 2019. “Public Inspiration :Jurnal Administrasi Publik Implementasi Kebijakan Padat Karya Tunai ( PKT ) Pada." Public 
Inspiration: Jurnal Administrasi Publik 4(2): 7182. https://ejournal.warmadewa.ac.id/index. php/public-inspiration\%0AImplementasi.

Creswell, John W. 2015. Penelitian Kualitatif \& Desain Riset. Yogyakarta: Pustaka Pelajar.

Creswell, John W, and Vicki L Plano Clark. 2018. Designing and Conducting Mixed Methods Research.

Darmi, Titi, and Iqbal Miftakhul Mujtahid. 2019. "Journal of Indonesian Public Administration and Governance Studies (JIPAGS) p-Issn: 25490435 e-Issn: 2549-1431." Journal of Indonesian Public Administration and Governance Studies 3(1): 547-66. http://dx.doi.org/10.31506/ jipags.v3i1.5484.

Dian, Tiara Rama, and Farid Muhammad Ma'ruf. 2019. "Pemberdayaan Masyarakat Melalui Program Padat Karya Tunai (Studi Kasus Desa Plandaan Kecamatan Kedungwaru Kabupaten Tulungagung)." Publika 7(4): 1-58. https:// jurnalmahasiswa.unesa.ac.id/index.php/ publika/issue/view/1706.

Fito, Irpan. 2015. "Faktor-Faktor Penyebab Pengangguran Di Desa Teratak Kecamatan Rumbio Jaya Kabupaten Kampar." Journal of Chemical Information and Modeling 2(1). https://jom.unri.ac.id/index.php/JOMFSIP/ article/view/4797/4680.

Herdiana, Dian. 2019. "Kecenderungan Perilaku Koruptif Kepala Desa Dalam Pembangunan Desa." Matra Pembaruan 3(1): 1-11. http:// doi.org/10.21787/mp.3.1.2019.1-11

Herdiyana, Deni. 2019a. "Implementasi Padat Karya Tunai Dalam Menurunkan Lampung Dan Riau." Jurnal Penelitian Pendidikan dan Ekonomi 16(2): 176-88. https://doi.org/10.25134/ equi.v16i02.2193.
Herdiyana, Deni. 2019b. "Pengaruh Padat Karya Tunai Terhadap Tingkat Kemiskinan Di Pedesaan Prov. Jawa Barat Dan Riau." Jurnal Ekonomi dan Industri 20(3): 49ji65. http:// dx.doi.org/10.35137/jei.v20i3.360.

Meleong, Lexi J. 2017. Metodologi Penelitian Kualitatif. Edisi Revi. Bandung: PT. Remaja Rosdakarya.

Nafidah, Lina Nasehatun, and Nur Anisa. 2017. "Akuntabilitas Pengelolaan Keuangan Desa Di Kabupaten Jombang." Akuntabilitas 10(2): 273-88. https://doi.org/10.15408/akt. v10i2.5936

Nagamatsu, Shingo. 2014. "Are Cash Forwork (CFW) Programs Effective to Promote Disaster Recovery? Evidence from the Case of Fukushima Prefecture." Journal of Disaster Research 9(2): 161-175. http://doi.org/10.20965/jdr.2014. p0161.

PKN-STAN, BKF dan. 2018. Kajian Dana Desa (Analisis Empiris Badan Usaha Milik Desa, Kesempatan Kerja, Dan Infrastruktur Pada Seribu Desa Di Indonesia. https://fiskal.kemenkeu.go.id/ data/document/2019/kajian/Kajian_dana_ desa.pdf.

Sugiyono. 2007. Metodologi Penelitian Kualitatif. Bandung: Alfabeta.

Wahyuddin, Wahyuddin, Arroyyan Ramly, Muslim A. Djalil, and Mirna Indriani. 2019. "Efektivitas Pemanfaatan Dana Desa Dalam Mengentaskan Kemiskinan Di Kec Kuala Kabupaten Nagan Raya." NUANSA: Jurnal Penelitian Ilmu Sosial dan Keagamaan Islam 16(2): 181. http://dx. doi.org/10.19105/nuansa.v16i2.2410. 